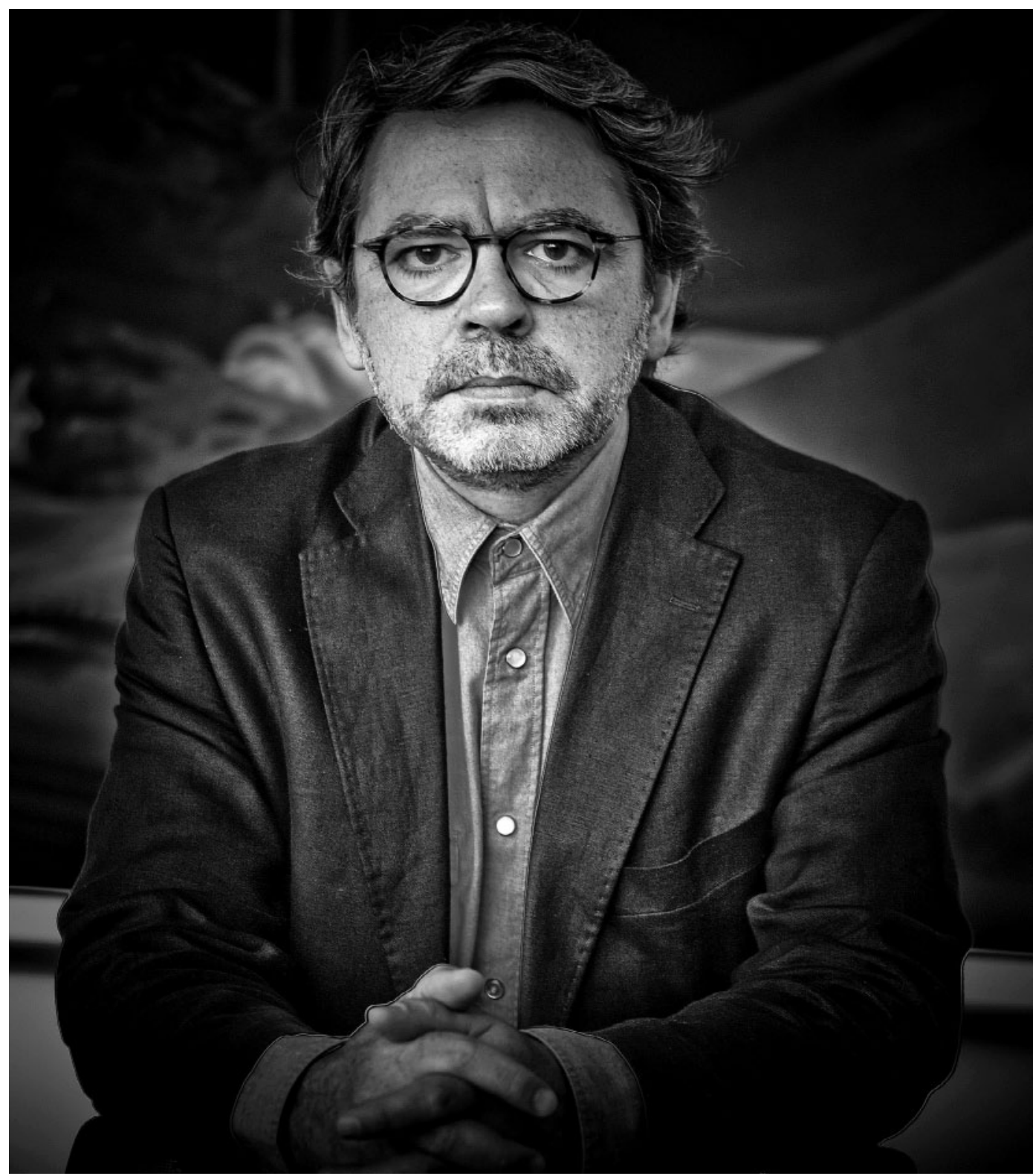

\title{
Nuno Carinhas
}

\section{Sobre levantamentos e outros pronunciamentos}

\section{Alexandra Moreira da Silva e Paulo Eduardo Carvalho}

O percurso criativo de Nuno Carinhas caracterizou-se, durante muito tempo, por uma espécie de errância ou demanda artistica, que melhor explica a natureza multifacetada e independente da sua inscrição no domínio vasto das artes cénicas portuguesas: actor, artista plástico, cenógrafo e/ou figurinista para dança e teatro, mais fugaz dramaturgo e realizador, encenador. Muitos dos seus procedimentos cénicos denunciam uma vivência profundamente atenta às mais variadas expressões artisticas da contemporaneidade, sobretudo aquelas propostas que, da fotografia à instalação, trabalham o espaço. Para além de inúmeras colaborações com uma grande diversidade de criadores portugueses, a sua versatilidade tem-Ihe permitido a criação de espectáculos de concepção mais autoral, dominados pela busca de "climas sensorais" e apostados na exploração das oportunidades imprevistas oferecidas por uma grande variedade de materiais e de sugestões, cujos ensinamentos tem sabido recuperar na exploração dos repertórios e dos palcos mais convencionais. A sua aventura mais recente como director artístico do Teatro Nacional São João foi um motivo adicional para uma conversa, realizada no passado dia 28 de Fevereiro, na qual se tentou traçar etapas do seu percurso, perceber o seu fascínio pelo "levantamento" dos espectáculos e registar outros pronunciamentos sobre a nossa comum realidade teatral. 
Nos dados compilados pela CETbase, o teu nome aparece como actor num espectáculo com o título Luz fria, do Proscenium - Grupo de Teatro do Sindicato Nacional dos Profissionais de Escritório do Distrito de Lisboa, em 1965, quando tu terias 11 anos. Isto é verdade ou é um erro da CETbase?

Eu já não me lembro de ter entrado nesse espectáculo, mas é verdade que entrei nalguns espectáculos como "mascote" ou quando era preciso fazer papéis de criança porque os meus pais faziam parte desse grupo. Luz fria era, aliás, um texto extraordinário sobre o conflito atómico, mas lembro-me muito bem que entrava o Rogério de Carvalho. E é possível que eu tenha participado, mas não me lembro. Recordo-me de outros, como As alegres comadres de Windsor, uma silva vicentina, e outros, porque tenho fotografias que os documentam.

Na verdade, a CETbase regista ainda outras participações tuas em produções do Proscenium, como o Rei Lear, em 1969, e num outro espectáculo que se chamava Peraltas e sécias, em 1972. Pode dizer-se que estes foram os teus primeiros contactos com o teatro e que foi por causa destas experiências que o teatro acabaria por acontecer na tua vida?

Desde os cinco anos que me habituei a ouvir textos de teatro e a assistir a ensaios, a ver preparar projectores e a confeccionar fatos, a ajudar o meu pai a decorar os textos e a minha mãe a ler os textos em casa ou nos ensaios, etc. Com certeza que isso contagiou, de forma indelével, o meu percurso. Mas como houve um hiato tão grande, depois, entre fazer isso e começar a fazer outras coisas, como ter ido parar a Belas-Artes, não me apercebi imediatamente desse contágio. Hoje, não posso negar que poderá ter tido algum efeito decisivo.

A tua entrada para Belas-Artes surge na sequência normal da escolaridade?

Sim, depois de ter chumbado...

Certo, mas foi a tua primeira opção em termos de formação superior?

Sim, pensei também em ir para História, mas acabei por ir para Belas-Artes.

Mas então, após o tal hiato que referias, o teu regresso ao contacto com o teatro acontece ainda paralelamente à tua frequência de Belas-Artes? Porque o teu nome volta a aparecer, novamente na qualidade actor, mas num contexto menos amador, em produções do Grupo de Teatro Hoje e da Barraca, em 1975-1976...

Há, de facto, um período de tempo em que eu não tenho contacto nenhum com o teatro. Tenho primeiro com a dança. Recordo-me de, numa disciplina de pintura, nos ter sido proposto fazer um trabalho de cenografia, acompanhando um espectáculo que o Ballet Gulbenkian estava a produzir, com coreografia do Carlos Trincheiras e cenografia da Emília Nadal. A ideia era nós irmos ver o ensaio e fazermos a nossa própria proposta para o que tínhamos visto. E essa é a minha primeira aproximação ao Ballet Gulbenkian, para além de espectador assíduo da Companhia desde o Teatro Politeama. Mas, sim, ainda estava na Escola de Belas-Artes quando apareceram esses espectáculos: a Mariana Pineda [Grupo Teatro Hoje, 1975] A festa do colégio dos alfinetinhos de segurança do colchão de molas do sagrado coração [0 Grilo do Pinóquio, 1974] com o João Perry..

\section{Mas como é que surge, então, este "regresso" ao} teatro?

Boa pergunta... Eu fui mantendo algum contacto com o teatro através do Primeiro Acto, em Algés, que era um espaço muito activo, de aprendizagem e de resistência, por onde passou muita gente, entre actores e artistas de outras áreas. Foi aí, por exemplo, que conheci o Jorge Listopad e que fizemos uma peça de um autor chinês que se chamava Milho para o oitavo exército - eu já não me recordo se este era o título original ou o nome que se the deu para fugir à censura. E foi daí que, pela mão do Listopad, fui parar à produção do Platonov, numa companhia com um elenco de luxo [Companhia de Teatro da RTP, 1974]. Depois dá-se o 25 de Abril. E surgem aqueles espectáculos de que falávamos e as minhas colaborações mais tarde como cenógrafo e figurinista...

Há participações tuas como actor até ao início dos anos oitenta, num espectáculo com o título Rei Ramiro [GTN - Grupo de Teatro da Nova, 1982].

Não, nesse espectáculo não participei como actor, só desenhei o cartaz. 0 último espectáculo que fiz ainda como actor foi com o Ricardo Pais, o Terceiro mundo, em 1981, no espaço da Nova, é verdade.

E como é que acontece essa passagem da experiência como actor para as valências de cenógrafo e figurinista? Isso começa a acontecer logo na Barraca, em que participe primeiro como actor [A cidade dourada ou Nem tudo o que luz é ouro, 1976], mas logo a seguir também nos domínios da cenografia e do guarda-roupa [Histórias de fidalgotes e alcoviteiras, pastores e judeus, mareantes e outros tratantes, sem esquecer suas mulheres e amantes, 1976]. Mas também será por volta dessa altura que começa a minha colaboração com o Ballet Gulbenkian, que aconteceu porque, uma vez, eu tive a oportunidade de participar num dos ateliês coreográficos que a companhia desenvolvia com os seus próprios bailarinos e acabei a fazer um projecto com o Vasco Wellenkamp. Os meus trabalhos para a Gulbenkian começam muito antes das minhas colaborações com a Olga Roriz. E para ganhar a vida fazendo o que mais gostava, comecei a trabalhar, com diversos encenadores e diferentes companhias. 



Nuno Carinhas,

1986,

fot. Mário Cabrita Gil., Idade da Prata, Lisboa, Imprensa Nacional-Casa da Moeda.

Porque é que abandonaste a experiência de actor? Porque como actor era uma desgraça! Não tinha estrutura, não tinha "estofo", para aquele tipo de trabalho. E além disso, tinha para mim muito claro o que seria um bom intérprete, por isso o meu sentido crítico acabou por me convencer a abandonar tal pretensão. Não tinha mesmo a estrutura física adequada: recordo-me de terminar alguns ensaios ou espectáculos com imensas dores nas costas. Achava que nem voz tinha. $E$, realmente, o que sempre me interessou nos espectáculos foi o seu levantamento, a construção da sua estrutura interna, a dramaturgia. Dai a cenografia e os figurinos como elementos decisivos.

Mas percebeste cedo que o que gostarias de vir a fazer era encenar?

Eu demorei muito tempo até encenar, até querer encenar. Aconteceram algumas coisas de passagem, exercicios finais em workshops, experiências que partilhei com o Ricardo Pais, por exemplo, no âmbito de Saudades ou Ninguém [1978], na qualidade de assistente de encenação, mas passaram muitos anos até eu tomar coragem para encarar uma primeira encenação, "a sério", além de uns happenings e performances em galerias e bienais.

Finalmente, após esses anos todos de colaboração com a Gulbenkian, como cenógrafo e figurinista, tanto no Ballet Gulbenkian como no ACARTE, reuni coragem para propor à Dra. Madalena Azeredo Perdigão o projecto de encenação do Amor de Dom Perlimplim com Belisa em seu jardim [1987], para o qual tinha reunido um conjunto de colaboradores sui generis, nos quais depositava inteira confiança. E depois disso, voltei a ficar muitos anos sem encenar.

Quando falas em muito tempo, estamos efectivamente a falar de um período de cerca de dez anos entre as tuas colaborações com o Ricardo Pais, em espectáculos como Saudades [1978], Ninguém e Terceiro mundo, e esse Lorca no ACARTE, em 1987. Já agora, recordaste como aconteceu o encontro com o Ricardo Pais? 0 Ricardo estava em Portugal há relativamente pouco tempo e terá tentado saber quem poderia funcionar como assistente de encenação, já a pensar no projecto do que viria a ser o Ninguém, e tanto quanto me recordo terá sido o João Perry a sugerir o meu nome. Eu, na altura, estava a fazer a Mariana Pineda, do Grupo Teatro Hoje, no auditório da Sociedade Portuguesa de Autores (SPA), e creio que foi aí que o Ricardo apareceu, conversámos e começámos a trabalhar juntos, a que horas fosse do dia ou da noite, entre telefonemas.

E que memória guardas dessa experiência do Ninguém? Eu acho que há uma coisa que resume esses tempos, uma nota no texto do Ricardo para o programa desse espectáculo, na qual ele diz qualquer coisa como: "Esta 


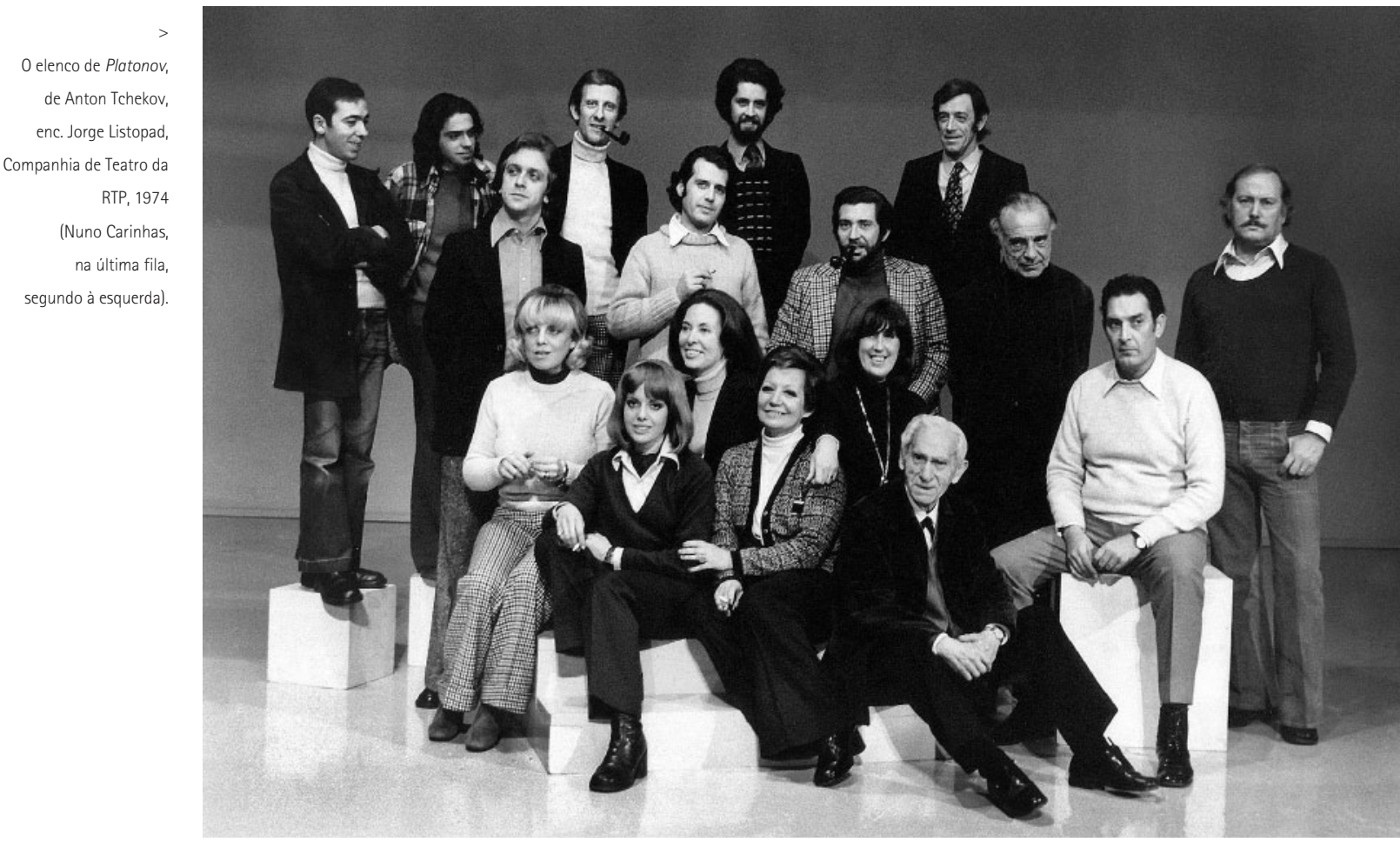

encenação deve uma menção especial ao Nuno Carinhas a quem pertence desde a origem". Isso diz muito do que poderá ter sido o meu envolvimento no espectáculo e num projecto cuja preparação levou muito tempo, que chegou a ser concebido para o Coliseu dos Recreios, com uma forte componente circense, e que depois se foi adaptando às circunstâncias e às possibilidades até acabar no Teatro da Trindade. Eu acho que havia uma capacidade de entendimento delirante, que nessa altura eu e o Ricardo conseguiamos ter, e que nos permitiu avançar. A dimensão poética, a estratégia da colagem, a nivel da dramaturgia, tudo isso eram coisas que me fascinavam muito. E o que para mim foi extraordinariamente gratificante foram as sessões de trabalho que conduziram e acompanharam a criação do espectáculo, nas suas diferentes fases. A possibilidade de me ter cruzado com o Alexandre O'Neill e com a Maria Velho da Costa, por exemplo, faz parte das memórias desse espectáculo. E eu sempre admirei muito a dinâmica que o Ricardo tinha de levar a água ao seu moinho, de ter o prazer diplomático que se impunha ter para conseguir fazer as coisas. No teatro português, não havia muitos criadores free lancers, estava tudo muito concentrado nos grupos, e essa "independência" era uma coisa que a mim me fascinava. Aliás, o mesmo se passara com o projecto do João Perry, A festa do colégio dos alfinetinhos..., que acabámos todos por ter que pagar para conseguir fazer. Depois, ainda com o Ricardo, também houve aquelas experiências, com o Terceiro mundo e os Cómicos concerto, com o Carlos Zíngaro e a Emília Rosa por parceiros, em que a vontade do experimentalismo nos aproximava mais da performance do que do modelo teatral. Claro que isso nos ajudou a todos muito. E muitas outras pessoas, algumas delas estando próximas do teatro, não eram parecidas com as pessoas do teatro que se fazia na altura. 0 lado multidisciplinar e multimédia, ainda que com meios rudimentares, que hoje nos parecerão ridículos, mas com alguma sofisticação sonora e musical, era muito fascinante. E foram-se buscar os poetas, praticou-se a colagem, uma dramaturgia da fragmentação, para criar universos muito distintos daqueles que poderiam existir se estivéssemos a trabalhar peças de repertório.

Experimentaram-se narrativas que cruzavam cenas ao vivo com imagens de vídeo e truques de magia.

De algum modo o que estás a dizer é que tudo isso funcionou como uma espécie de laboratório? Exactamente. A própria exploração de espaços não convencionais, como a sala da Sociedade Nacional de Belas Artes ou a grande nave que existia no Museu Nacional de Arte Antiga, ou a garagem do antigo quartel para onde foi a Universidade Nova. Eram experiências que funcionavam como desafios às próprias linguagens cénicas e a nós próprios enquanto "intérpretes". A movida lisboeta dos anos oitenta impelia ao desbravamento de novas realidades.

Para fechar esta questão: achas que todas essas experiências, incluindo as que tiveste como actor, foram importantes para o teu trabalho futuro como encenador?

Sim, acho que sim. Todas as experiências que se possam ter quanto ao levantamento de um projecto teatral, desde a tradução até à representação, são necessariamente importantes. E aí recupero as próprias experiências da infância, como o relacionamento do corpo com o espaço.

Alguma vez, no contexto de todas essas variadíssimas experiências e colaborações, experimentaste o fascínio por alguns dos actores com quem te foste cruzando? Todos os intérpretes me fascinaram sempre muito, tanto no teatro como na dança - aqui com o factor acrescido de eu não ser capaz de experimentar o mister dos bailarinos. 0 facto de querer estar no levantamento dos espectáculos não tem a ver só com o lado cerebral e estrutural da questão; era também esse trabalho da construção dos 

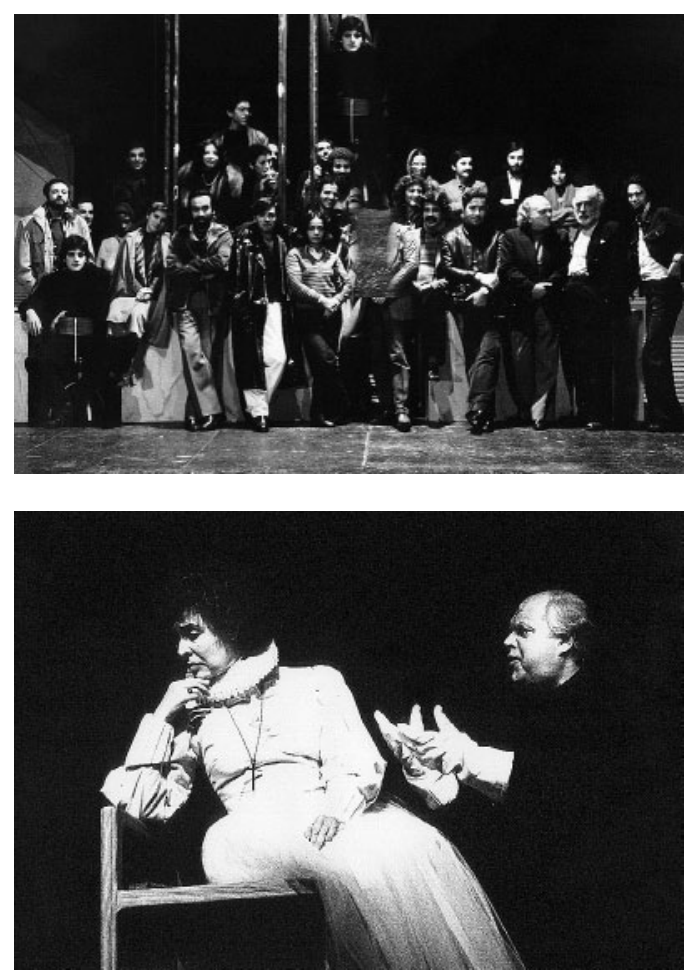

intérpretes e da relação dos encenadores e dos coreógrafos com os actores e bailarinos que me interessava. Perceber como é que se podia potenciar o que os intérpretes tinham dentro de si para se percorrer um determinado caminho e depois chegar a um resultado. Poder assistir à construção de um solo para e com Ger Thomas, ver como ele tornava seus os gestos do coreógrafo, inventando a sua própria narrativa, é um episódio inesquecivel. Trabalhar como cenógrafo e figurinista, poder participar nos ensaios, era também um pretexto para estar livre para esse exercício de quase voyeurismo em relação ao levantamento e construção dos espectáculos. E eu fiz isso sempre sem nenhum sentido de censura em relação ao trabalho de cada um: achei sempre fascinante, mesmo quando depois o resultado poderia ser menos apreciável. Aliás, num dos primeiros textos que eu escrevi quando comecei a encenar, chamei aos actores "anjos" ou qualquer coisa assim. Quando descobri que não tinha essa capacidade de ser actor, os intérpretes passaram a ter uma importância ainda maior. $\mathrm{E}$, se calhar, tudo isto é muito psicanaliticamente explicável porque eu sempre achei que o meu pai era um extraordinário actor, um intérprete fantástico, à força de muito trabalho e persistência.

0 exercício das tuas valências de cenógrafo e figurinista fazem-te cruzar com uma variedade imensa de criadores portugueses, consequência da condição de free lancer que abraças...

Mas eu sempre achei que isso era uma obrigação, precisamente porque eu não tinha uma formação especifica. Pareceu-me sempre que se aprendia fazendo, por isso, estive sempre disponivel para abraçar outros desafios. E essa variação, entre criadores e companhias, fazia parte desta condição. É uma questão de disponibilidade e de curiosidade. Devo muito aos que me foram retribuindo a atenção, sobretudo aos mais velhos, como o Pedro Lemos, a Fernanda Alves e o Ernesto Sampaio, ou o José Ribeiro da Fonte, o Orlando Worm, o Jorge Salavisa, a Madalena Perdigão, o mestre Lagoa Henriques.

Já explicaste há pouco como surgiu a tua primeira encenação em 1987. A pergunta agora é porque é que ela não foi seguida mais imediatamente de outros trabalhos como encenador e só em 1993 voltas a surgir como responsável pela direcção de um espectáculo, com a Comédia sobre a divisa da cidade de Coimbra? Pois não sei. Terá sido fruto das circunstâncias. Era preciso que eu tivesse uma enorme segurança em relação à organização e ao sítio em que ia fazer uma primeira experiência. E realmente eu senti-me "protegido" e bemvindo no espaço do Centro de Arte Moderna da Gulbenkian e tinha um grupo de pessoas à minha volta que me garantiam algum conforto. Depois, como era sensivel a alguma susceptibilidade ou resistência que pudesse haver nas estruturas de produção, eu também nunca me propus a fazer coisas. Naturalmente, podem ter falhado algumas aproximações a alguns grupos ou projectos, mas eu sempre achei que as coisas deveriam aparecer de uma forma mais ou menos orgânica, sem forçar para fazer só porque tinha uma boa ideia na cabeça. Para os meus devaneios pessoais, eu tinha sempre essa "arte mais intima" que é a pintura; podia colmatar a necessidade de expressão pessoal por essa via, sem estar dependente de ninguém. Entretanto fui sendo pai, dei aulas, fiz algumas comunicações e expus os meus trabalhos.

Até 1987 e 1993 ou, se preferires, 1996, data a partir da qual passas a encenar com mais regularidade, serás capaz de recordar alguns trabalhos que tenhas feito no domínio da criação de cenografia e/ou figurinos como mais felizes ou mais marcantes? Um exemplo entre muitos possíveis: as portas do Treze gestos de um corpo [1987], no Ballet Gulbenkian.

Todas as experiências foram marcantes e muito importantes, porque ter dedicado tanto tempo a ver a criação dos espectáculos foi sempre um enorme privilégio. Além do mais, talvez porque fosse lento, eu precisava de estar junto das pessoas que faziam e próximo do percurso de criação. Passar o dia nas caves onde ensaiava o Ballet Gulbenkian ou passar as noites nos diversos espaços onde ensaiavam as estruturas de produção teatral com quem eu ia trabalhando, tudo isso fazia com que cada projecto tivesse o seu valor e a sua importância. Poderá ter havido algumas experiências que, no final, eu possa ter chegado à conclusão que o melhor era não ter estado lá, mas mesmo essas eu não posso dizer que não tivessem sido importantes.

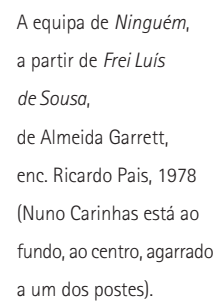

Frei Luis de Sousa, de Almeida Garrett, enc. Jorge Listopad, cenário e figurinos de Nuno Carinhas, ACARTE, 1986 (Carmen Dolores e Carlos Wallenstein). 
À procura da tragédia,

enc. Orlando Neves, cenário de Nuno Carinhas, ACARTE, 1986.

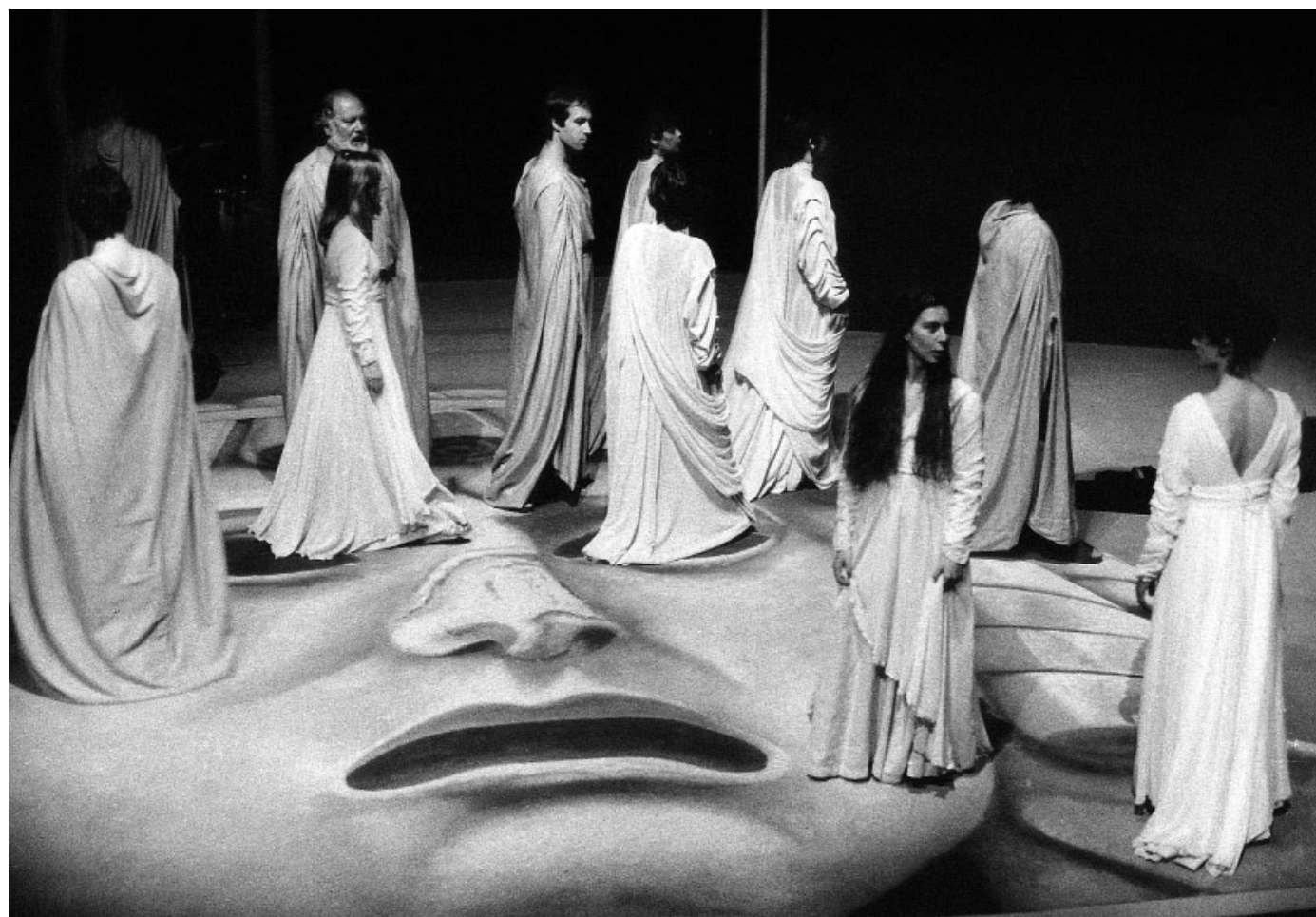

Claro que a experiência com o Ballet Gulbenkian foi extraordinária, mesmo em termos de aprendizagem: tudo tinha de ser muito bem concebido antes, a pensar naquele magnífico auditório, e depois era chegar, instalar e fazer. E havia muitas condicionantes, como a dimensão, a ausência de uma teia, o próprio facto de ser para dança. Essa fase do Ballet Gulbenkian, cerca de dez anos mais ou menos regulares, foi extraordinariamente importante, ate pela elementaridade do trabalho que me era exigido: eu tive de aprender a conceber coisas muito simples em termos de aparato cénico para que tudo pudesse funcionar. E eu acho que rapidamente comecei a transportar essa elementaridade também para o teatro. Ou então já seria uma tendência pessoal, não sei. Enquanto cenógrafo, onde aprendi a ver fazer luz foi justamente nos ensaios do Ballet Gulbenkian, ainda sem bailarinos, ao lado do Orlando Worm, a iluminar o espaço que estávamos a trabalhar, só com a presença dos figurinos, para se ter a noção do efeito da luz sobre a roupa. E isso é uma experiência única. Aquele espaço era uma espécie de grande laboratório. Tive o privilégio de conhecer os Irmãos Martins, fantásticos cenaristas que pintaram panos de fundo a partir de maquetas pictóricas que eu tinha realizado em formatos pouco maiores que uma folha A4. E assisti à manufactura de centenas de fatos produzidos no excelente atelier de guarda-roupa da Fundação. É por isso que me custa a ausência total de documentação do que foi o Ballet Gulbenkian. Todas as experiências tidas em companhias estrangeiras foram muito gratificantes e deram um alento particular, porque conferiram confiança. Estando a trabalhar fora das estruturas habituais e confrontado com profissionais e públicos outros, os resultados foram sendo positivos.

Entre a projecção de uma poética própria e as condicionantes resultantes das conjunturas de produção com que foste lidando, a verdade é que a tua abordagem à cenografia é muito pouco arquitectónica e muito mais constituída pelo recurso a elementos dotados de uma certa, digamos, singeleza.

Para mim, a arquitectura sempre esteve fora. 0 facto de eu poder trabalhar no grande auditório da Gulbenkian, na sala do Centro de Arte Moderna - na qual eu tive a oportunidade de fazer quatro espectáculos sequenciais, no âmbito do ciclo d'O retorno à tragédia -, ou num espaço tão diverso como a Casa da Comédia, ou em espaços não convencionais, isso sempre me deu uma elasticidade muito grande de associar o pensamento ao lugar, primeiro, e depois ao próprio espaço que se pretendia enquanto território da ficção. Todos os espaços envolventes eram o primeiro elemento; a arquitectura era a dos espaços onde as coisas se passavam. As portas de madeira dos Treze gestos de um corpo, por exemplo, decorrem da própria sala do grande auditório da Gulbenkian, com aquela extraordinária estrutura de madeira que nos ampara o olhar ao longo da plateia. E, por isso, as portas tiveram o mesmo tratamento que a madeira da sala. Quando pense o Espaço vazio [coreo. Olga Roriz, Ballet Gulbenkian, 1986], que é só um sofá em cena, obviamente que fui buscar um sofá desenhado nos primórdios da Fundação. É evidente que estes dispositivos foram depois transportados para outros palcos e outras salas. Mas é verdade que eu trabalho muito com o contágio da envolvência. Quando resolvi fazer a minha primeira exposição individual, sabia onde ela ia ser, isto é, na antiga De natura, na Rua da Rosa, que era uma loja pequena, com uma configuração especial, as paredes esponjadas a ocre, uma porta de vidro para a rua, ao fundo, uma outra sala mais pequena, um chão forrado a cairo, umas vitrinas ao fundo - e eu sabia que ia fazer uma exposição para aquele sítio específico. Não quer isto dizer que os desenhos não valessem por si, mas conhecer o espaço para onde eles se destinavam foi muito importante. Em todos os espaços, quando eu entrava neles, era importante que os "detivesse" e que não pensasse só na ficção em si, mas onde é que ela se iria passar: se 

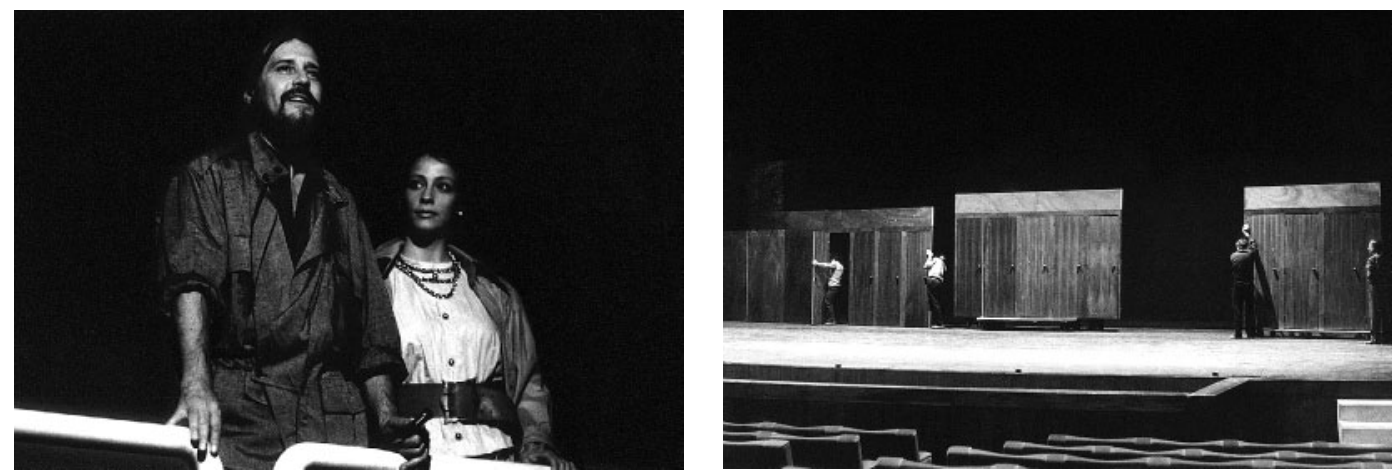

era em anfiteatro, se era num palco, se havia uma bancada, se o público estava à volta ou não, etc. A arquitectura estava presente, mas só a partir daí e não necessariamente como noção para criar um objecto cénico.

Em todo este período, até 1996, até esse início mais regular da tua actividade de encenador, foi sempre claro para ti que o modo como querias inscrever a tua actuação era como free lancer, isto é, nunca tiveste a tentação de constituir ou de integrar nenhuma estrutura que te permitisse um trabalho mais regular? Não. Haveria uma ou duas estruturas com as quais eu eventualmente me identificaria, e eu poderia ter experimentado funcionar dentro delas, mas isso não aconteceu. 0 facto de partilhar experiências, por exemplo, numa casa como a Fundação Gulbenkian foi decisivo não que eu me sentisse parte da Fundação Gulbenkian e nem sequer tinha nenhuma avença, o meu estatuto foi sempre o de free lancer. Nunca pensei fechar-me dentro de uma estrutura ou criar a minha própria. Acho que isso, de alguma maneira, sempre me causou alguma fobia e acho que era uma forma de estreitamento de procuras. Enfim, fui membro fundador da Barraca, mas fui o primeiro a sair. Esses acidentes de percurso levaram-me a ver, também, que ficar fechado numa casa não era o que mais se ajustava ao que eu queria fazer. Nada disto está desligado do resto, tem a ver com um percurso de vida... Eu acho que foi importante nunca ter tido a sensação de pertencer a sítio nenhum, não ter a obrigatoriedade de estar lá sempre, o que para mim, repito, funcionava como estreitamento de possibilidades. Mas também é verdade que eu nunca me preocupei em construir nenhum tipo de carreira, nada disto era muito pensado: era um sentimento, uma necessidade, uma forma de viver, sem ter de me fechar. 0 empenho em relação a cada um dos projectos era absoluto: tudo aquilo que eu tinha para fazer com determinadas pessoas em determinados projectos se esgotava em si próprio. E o ideal é isso, que não fique nada por explorar, por fazer, por identificar $\mathrm{e}_{\text {, }}$ portanto, o projecto acaba ali. Se voltar a encontrar-me com aquelas pessoas, muito bem, caso contrário, aquilo ficou ali como coisa absoluta.

0 que é que ficou destas duas primeiras experiências de encenação, o Perlimplim, em 1987, e a Comédia sobre a divisa da cidade de Coimbra, em 1993, para que em 1996 aceitasses aquilo que imagino que terá sido um convite para fazeres $O$ grande teatro do mundo? Tornou-se mais clara para ti a possibilidade de criação de espectáculos?
Fundamentalmente, tive a percepção de que seria capaz de liderar um projecto, em todas as suas valências e manifestações, sendo capaz de perceber que os objectos, porque eram raros, tinham neles coisas muito substanciais, tanto para mim próprio como em relação aos actores e às estruturas onde foram desenvolvidos. São objectos distantes, mas não são objectos assim tão díspares - por exemplo, a Comédia sobre a divisa da cidade de Coimbra só podia ser feito naquela cidade, com aquele grupo [Escola da Noite]; muito provavelmente, desde o Gil Vicente mais ninguém teria feito aquela peça. Eu era dado a algum "esgotamento" do que falava há pouco: cumpria-se a tarefa e cumpria-se de uma forma obsessiva e não se pode permanecer assim sempre, por isso, depois tem se deixar passar tempo.

Para alguém que vinha com um percurso tão demorado na criação de espaços cénicos, como é que foi ter de trabalhar com outras pessoas com a responsabilidade pela cenografia?

Por um lado, eu tinha adquirido formas de diálogo muito dinâmicas, entre mim próprio como cenógrafo e os encenadores ou coreógrafos com quem trabalhava. Por isso, nessa altura, achei que estava pronto para fazer o jogo ao contrário. No caso do Perlimplim, eu sabia que estava a trabalhar com uma pessoa com um gosto muito apurado, que era o caso da Vera Castro. Em relação ao João Mendes Ribeiro, para o Gil Vicente, eu não o conhecia tão bem, por isso, tratou-se de arriscar que alguém me pudesse propor determinado objecto, me condicionasse a ele, e depois eu responder a isso. Nessa altura, isso era um jogo bem-vindo. Seja como for, nessas experiências, eu passei sobretudo para o jogo com os intérpretes, por isso, tudo o que vinha de fora já não era assim tão estranho...

0 que estás a sugerir é que, de algum modo, deslocaste os teus objectos ou zonas de investimento?

Sim, embora as coisas não deixassem de estar relacionadas. Eu já tinha experimentado tantos espaços que não seria agora um outro, já cenicamente conformado, que me condicionaria tanto. No caso da Comédia sobre a divisa da cidade de Coimbra, estamos a falar de uma caixa de madeira, que era uma ideia à volta da qual andavam tanto a Escola da Noite como o João Mendes Ribeiro. 0 que constituía um desafio muito interessante. Por exemplo, quando fiz 0 grande teatro do mundo, em 1996, teria sido incapaz de assumir todas as valências, seria trabalho a mais, precisamente porque, nessa altura, o trabalho de encenador seria o que mais me inquietava e não seria capaz de acumular outras responsabilidades criativas.
O indesejado de Jorge de Sena, direcção artistica de Jorge Listopad, cenário e figurinos de Nuno Carinhas, ACARTE, 1986 (Sinde Filipe e Alexandra Lencastre).

Montagem do cenário de Nuno Carinhos, para Treze gestos de um corpo coreografia de Olga Roriz Ballet Gulbenkian, 1987. 
0 grande teatro do

mundo,

de Calderón de la Barca, enc. Nuno Carinhas, TNSJ, 1996 (Jorge Vasques e João Reis), fot. João Tuna.
Como é que foi vivida a experiência de colaborar com um projecto, então, emergente como era o Teatro Nacional São João, em 1996?

Desde logo, como uma enorme responsabilidade, mas também como a possibilidade de reatar um diálogo com o Ricardo [Pais] que tinha sido interrompido muito tempo antes, mas também porque achei que era, mais uma vez, uma questão de acolhimento: se o Ricardo apostava em mim para fazer determinados projectos, alguns deles tão complicados como 0 grande teatro do mundo, já dentro de um ambiente de grande euforia e de brilhante organização como era o Teatro Nacional São João, e com todo o conforto que se podia sentir dentro dessa estrutura, então eu tinha os elementos reunidos para a mais positiva das acções. Nesses anos todos, eu tinha ficado sempre com o desejo muito retido de empreender uma nova encenação, à espera de um momento propício para isso acontecer. Foi com essa euforia que parti para a criação d'0 grande teatro do mundo e, mais tarde, para A ilusão cómica [1999]. Ter comigo criadores como Vin Burmhan Nuno Lacerda Lopes, António Lagarto ou Francisco Leal, Carlos Assis ou Dominique Bruguière, eram condições inéditas com as quais me confrontei no tempo certo para poder rentabilizar os meus devaneios.

Igualmente a partir de 1996, em paralelo com as transformações do próprio sistema teatral português e uma acentuada pulverização de projectos e unidades de produção, foi-se tornando cada vez mais possivel ir articulando a regularidade das tuas colaborações com o TNSJ, em diferentes formatos e valências, com colaborações com outras estruturas. Tal facto leva-te a trabalhar em contextos criativos e sistemas de produção completamente distintos, tanto no Porto (Teatro Bruto, ASSéDIO, Ensemble) como em Lisboa (Cão Solteiro, Escola de Mulheres, Novo Grupo/Teatro Aberto). Como é que foi ir trabalhando no contexto dessa diversidade?

Eu acho que identifico duas estruturas como tendo sido decisivas a partir de dada altura: o Cão Solteiro, por um lado, e o TNSJ, por outro. Duas âncoras em duas cidades. Depois, há um outro mapa que se constrói à volta da cidade do Porto. São campos de exploração completamente diversos, que me proporcionam um leque de experimentações muito amplo. No caso do Cão Solteiro, o trabalho a partir de guiões muito singulares, não preestabelecidos, e no caso do TNSJ, a possibilidade de me dedicar mais ao teatro de repertório. Há um espectáculo de passagem entre uma coisa e outra que, para mim, constitui uma espécie de ligação entre todas estas coisas


que é La dinamica dell'acqua [Teatro Bruto 1998]: é algo muito específico, que não tinha nada a ver com o trabalho no Cão Solteiro nem com o trabalho no TNSJ. Acho que funcionou como uma espécie de síntese de muitas coisas que andavam no ar. É um espectáculo que eu recordo: fazendo apelo à memória, de um momento para o outro ele aparece. 0 próprio facto de ter sido num espaço não convencional [Moagens Harmonia] foi muito marcante. Mas para regressar à vossa pergunta, continuava a ser importante não estar condicionado a nenhum desses projectos, o poder alternar. A partir de determinada altura, com algumas estruturas, eu talvez tenha tido pena de não ter havido uma insistência na colaboração: acho que senti isso em relação ao Teatro Bruto, por exemplo. Sentia que as pessoas paravam no momento exacto em que deviam continuar a pesquisa de um certo tipo de linguagem. Mas claro que isso tinha a ver com a minha condição de free lancer e o facto de os grupos desenharem a sua própria política interna.

A outra questão resultante dessa tua condição de free lancer prende-se com a própria construção de um repertório: na maior parte dos casos, ficavas dependente do que essas estruturas te convidavam para fazer. Isto não é, às vezes, indutor de algum tipo de frustração? 0 meu percurso é feito desses desfasamentos e não tenho resguardo em relação a isso. É algo que tem a ver com o tipo de inquietações que eu já tinha há umas décadas atrás: a ideia de que só se aprende fazendo e de que, provavelmente, eu nunca irei passar para outro plano a nível desta noção da aprendizagem, que é feita por estímulos e desafios, abertura de portas que, de outra maneira, eu nunca iria abrir. 0 ficar à mercê de propostas que me são feitas é um desafio muito grande, porque ou eu consigo corresponder aos projectos ou não. É como se um arquitecto dissesse que só projecta em terrenos planos, ou outro que só trabalha em terrenos em socalco ou um 


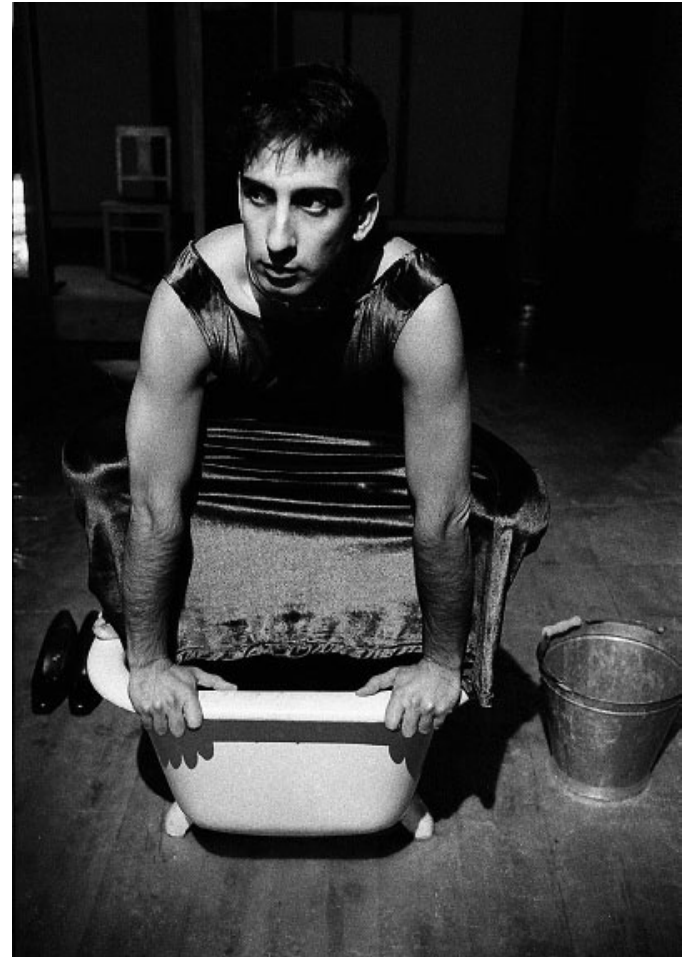

qualquer tipo de especialização que eu acho que o teatro não contempla. Nunca tive tempo para ter a veleidade de querer encenar um determinado texto. Por preguiça, talvez, ou o que se quiser. A minha experiência foi sempre a de estar completamente concentrado no projecto que tinha entre mãos. E felizmente os projectos foram-se sucedendo. Claro que fui tendo a fortuna de desafios de alguns colaboradores avisados que me foram assegurando alguma lógica em termos de repertório, proporcionando-me muitas vezes a relação com autores que eu nunca teria descoberto ou explorado não tivessem sido esses convites. Acho que a questão está em resolver "problemas". As coisas foram sendo assim e talvez eu já não tenha idade para que elas sejam de outra maneira. Claro que agora que, enquanto director do TNSJ, tenho a possibilidade de determinar aquilo que eu próprio quero fazer. Estes casos mais recentes, como os Tambores na noite, o Breve sumário da história de deus ou mesmo a Antígona, são coisas que estão dentro de mim, são textos que andam a bulir comigo há muito tempo. E agora estou na fase em que posso projectar tudo isso que não fiz antes.

Então este é o momento para perguntar o que é que leva alguém, com o percurso que estivemos aqui a tentar reconstituir, ainda que de forma sumária, a entusiasmar-se ao ponto de aceitar esse outro desafio de dirigir um dos dois únicos teatros nacionais que temos em Portugal. Porque é que, a dada altura, isso se torna entusiasmante ou, dito de outra maneira, o que é que te levou a aceitar o convite para dirigir o TNSJ? Especificamente o TNSJ, esclareça-se. Primeiro, porque é um sítio que me é agradável, por todas as condições que alberga, e porque eu fui construindo um determinando percurso dentro do próprio Teatro, com uma série de pessoas com as quais me identifico em muitos aspectos. Depois, de alguma maneira, porque não estava propriamente a substituir ninguém de forma abrupta. Foi-me confortável a ideia de

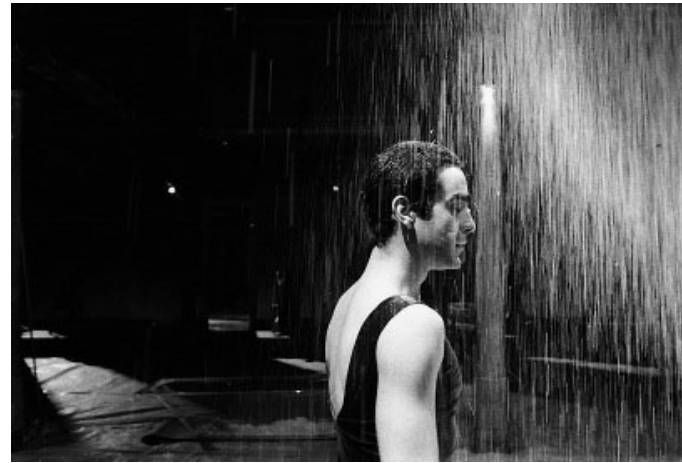

La dinamica dell'acqua, a partir de vários autores dir. Nuno Carinhas, Teatro Bruto, 1998 $(<$ Paulo Freixinho; $>$ Mário Santos) fot. Margarida Ribeiro.

que havia uma passagem de testemunho, que envolvia confiança e continuidade. Não defendo a sucessão dinástica, mas foi assim que aconteceu. Por outro lado, também porque já estava na altura de poder projectar alguma convicção do que eu acharia que seria dar a ver o teatro a nível nacional. $E_{1}$ ainda, o desejo de me pôr nessa posição que eu acho que as artes do espectáculo exigem e que é a missão pública: o que é que era isso de assumir essa posição. Não sou um programador, no sentido mais profissional do termo, porque não tive formação para isso nem nunca senti grande atracção por isso, mas acho que tenho - dada a minha experiência de andar por aí a entrosar-me com uma série de acontecimentos e estruturas - as condições para saber o que é que deve ser mostrado de maneira organizada e consequente. Sempre me coloquei muito no lugar do espectador, um espectador necessariamente especial, mas sempre gostei muito de ir ver sem preconceitos e não necessariamente coisas que só tivessem a ver comigo. Penso que esta é uma mais-valia importante para esta função. A direcção de um Teatro Nacional pode traduzir-se num percurso mais autoral, por parte do seu director, ou pode ser um percurso mais aberto. De qualquer maneira, considero que este ano que já passou, desde a minha nomeação até agora, e a programação desta temporada e toda a outra que já está projectada para a frente, tudo é tão meteórico que é necessariamente muito experimental e eu ainda não sei tirar as devidas ilações de tudo isto. Há, com certeza, o desejo de aproximar tanto geograficamente como do ponto de vista estético aquilo que se vai fazendo. Já percebi que estas novas funções retiram muito tempo e espaço à dita obsessão com que eu estava habituado a empreender os projectos, porque há uma natural deslocação, não digo dispersão, da atenção, algo a que eu não estava acostumado. Esta é uma nova fase que estou a viver. Os projectos são desenhados de outra maneira e precisam de uma abordagem que não me era familiar.

Mas isso também te permite evitar o tal fechamento de que falavas há pouco.

Sim, e eu acho que o desafio também foi bem feito, no sentido de eu ser só director artístico e não também presidente do Conselho de Administração. Nesse caso, eu acho que teria pensado muito melhor se aceitaria, porque não me sentiria tão confortável de imediato.

Tu próprio já foste adiantando que não te sentiste muito tentado, no início do teu mandato, a fazer grandes pronunciamentos ou a explicitar grandes desígnios, mas parece-te possível identificar algumas inflexões dentro dessa clara linha de continuidade? 


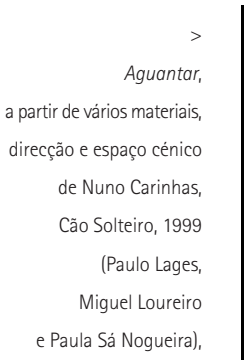

e Paula Sá Nogueira),

fot. João Tuna.

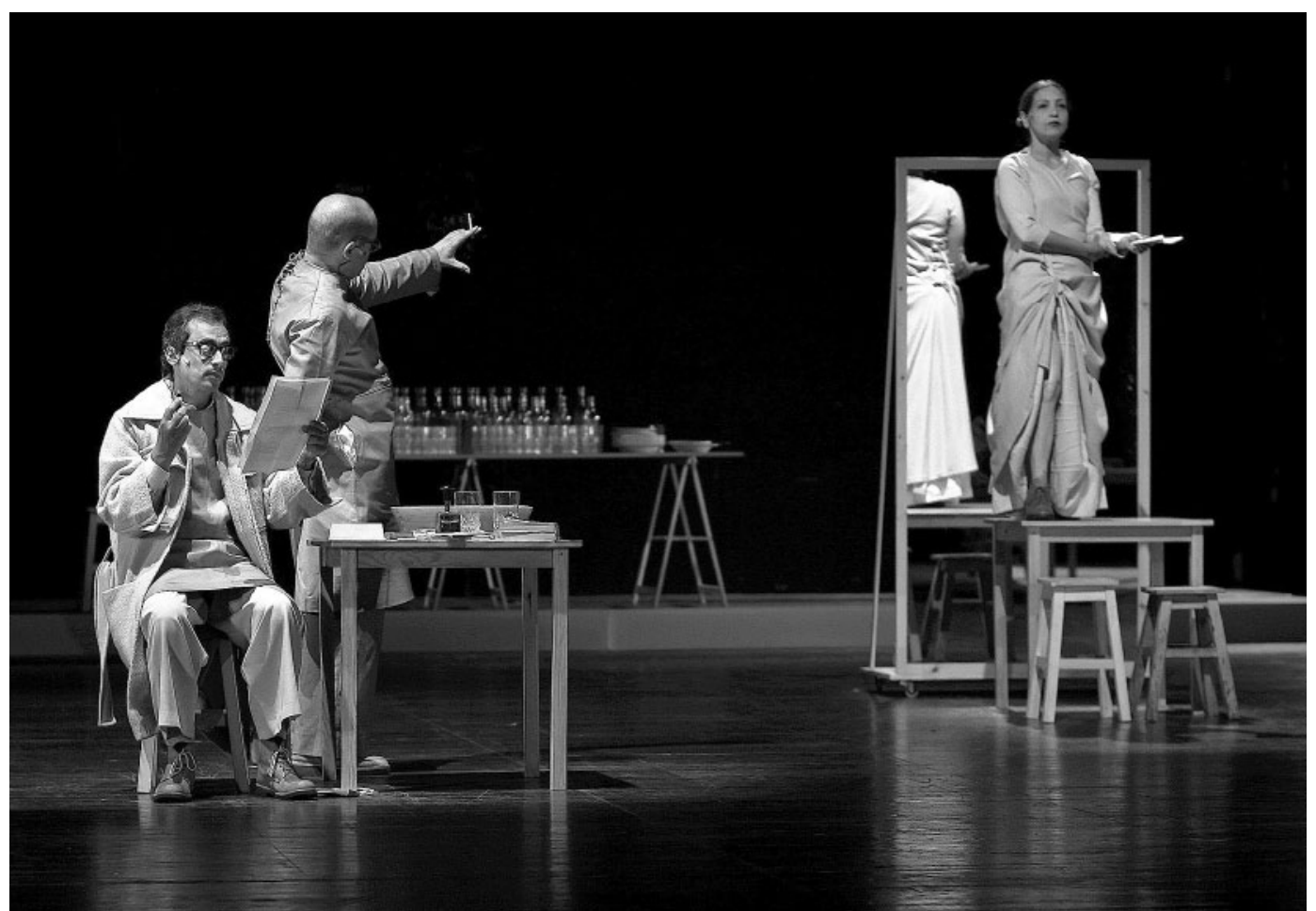

Eu identificava-me completamente com o que vinha sendo feito no TNSJ, por isso não trazia comigo o desejo de grandes rupturas. Havia que continuar todo um projecto que envolve o trabalho sobre os textos, de todas as épocas, dedicando uma atenção muito persistente à linguagem; e prolongar a tarefa de amostragem que o Teatro já vinha fazendo. Aquilo que eu posso achar que gostaria de fazer e que certamente já foi tentado ao longo destes últimos anos, prende-se, por exemplo, com a vontade de dessacralizar as salas, contrariar a identificação do trabalho que se faz numa ou noutra sala, sempre numa perspectiva de alargar os públicos. A nossa grande preocupação, do ponto de vista da comunicação, é sempre a de assegurar a máxima visibilidade e participação dos espectadores em qualquer dos espaços que gerimos. Sempre com a consciência da enorme responsabilidade local que temos, em termos do próprio tecido teatral da cidade, até pela ausência de alternativas para muitas das estruturas locais e nacionais. Durante muito tempo, eu trabalhei no TNSJ sem grande consciência ou preocupação relativamente ao modo como o Teatro se enquadrava ou relacionava com as outras estruturas da cidade. E, neste momento, essa é uma preocupação política muito importante.

Essa é uma preocupação que tem sido notória também relativamente a estruturas fora da cidade.

Claro. Enquanto viajante norte-sul, que sou, sempre me fez muita confusão que os espectáculos ficassem condicionados à sua cidade de origem. E num país tão pequeno, isso não faz sentido. Mas também é verdade que temos, hoje em dia, uma mobilidade muito mais activa associada também à entrada em funcionamento de outros teatros espalhados pelo país.

A situação ingrata no Porto passa pelo facto de o TNSJ ser a única entidade local que assegura essa possibilidade de circulação, o que é naturalmente aberrante para uma cidade com a dimensão e importância do Porto. Este facto parece sobrecarregar as responsabilidades do TNSJ, que é ao mesmo tempo, senão sobretudo, um teatro de criação. 0 problema da cidade, neste momento, não é de equipamentos, porque existem alguns, mas sim de lógicas de gestão. Concordas?

0 problema não é só do que deixou de haver, mas também do que não se criou de novo. Podia ter desaparecido alguma coisa, mas ter aparecido outra. Perante a possibilidade de, com os recursos disponiveis, poder "importar" espectáculos, eu acho que primeiro há que fazer um trabalho de projecção da criação nacional. Esta é, sem dúvida, uma linha programática muito importante. Por outro lado, a estratégia das co-produções, das partilhas, dos acolhimentos, etc., faz com que mais projectos possam ser realizados. Além disso, nunca me pareceu que a questão local fosse mais importante do que a nacional. A questão não é caseira, é cosmopolita. No Porto há uma exigência e uma focalização do público como não existe em Lisboa.

Há projectos de colaboração com outras instituições culturais da cidade do Porto, como Serralves ou a Casa da Música?

Sim, há, particularmente com a Casa da Música, desde a ideia de virmos a celebrar os dias mundiais da música e do teatro trocando de casa ou, por exemplo, projectos operáticos que podem vir a passar pelo TNSJ.

Pode dizer-se que, de algum modo, isso traduz uma vontade tua de continuar a cruzar linguagens? Sim. Há coisas para as quais eu não preciso de um comissário, como pode ser o planear de uma exposição ou de outra iniciativa qualquer que possa servir para gerar atenção à volta de um determinado projecto ou espectáculo, que são sempre o centro de tudo. Mas isto também porque me habituei à ideia de que o TNSJ não 


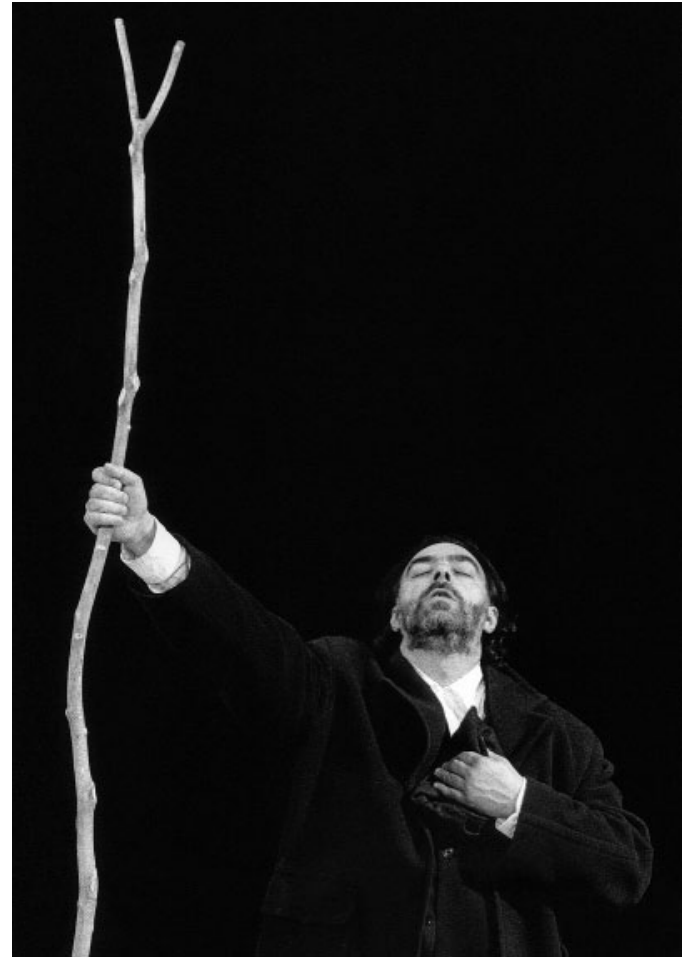

era só uma casa de espectáculos, não era só um teatro de portas abertas. Desde sempre se fizeram exposições à volta dos espectáculos, debates, publicações, iniciativas pedagógicas, etc. Há na Casa gente muito capaz e treinada que me acompanha na idealização e concretização de acções paralelas. Por isso, eu não estou a inventar nada. Há uma feliz coincidência de objectivos. Nos últimos meses o TNSJ tem vivido quase a ritmo de festival e não sei se isso se pode manter...

Mas não é essa também a vocação de um Teatro Nacional?

Acho que sim. No outro dia, o Bernard Sobel perguntavame quantas pessoas é que trabalhavam no Teatro e qual era o número do elenco e riu-se depois de eu Ihe responder, acrescentando: "Então não podes fazer mais do que um espectáculo por dia". Claro que isto tem a ver com a diferença de escala entre os teatros europeus, particularmente se pensarmos nos franceses e nos alemães, que conseguem ter uma equipa tão grande que Ihes dá para fazer tudo e mais alguma coisa.

Relativamente aos espectáculos que, neste curto espaço de tempo, programaste para tu próprio encenares Tambores na noite, de Bertolt Brecht, Breve sumário da história de Deus, de Gil Vicente, e Antígona, de Sófocles -, seria possível dizer que são todos eles textos dotados de uma inequívoca "seriedade de propósitos", de grande consequência filosófica ou interventiva, sentindo-se talvez a ausência de algo mais lúdico. Isto foi pensado ou aconteceu por acaso? Dito ainda de outro modo, estas escolhas resultaram de paixão ou de obrigação?

De paixão! Precisamente, como eu já disse, por serem textos que, das mais diversas maneiras, andavam há muito dentro de mim. Mas claro que são escolhas que também resultam do facto de eu achar que há um défice de

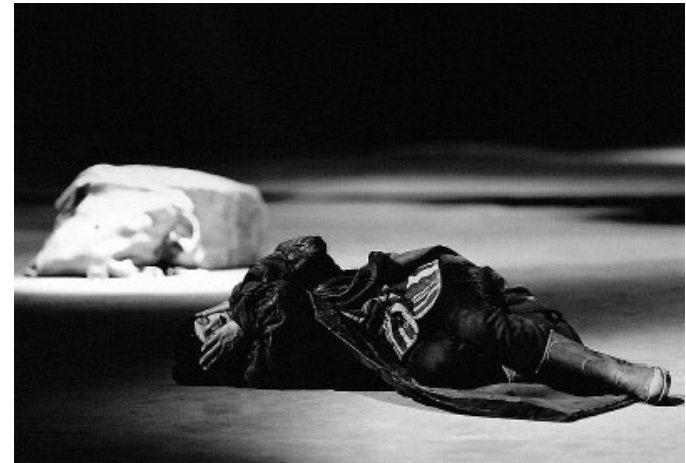

O fantástico Francis Hardy, curandeiro, de Brian Friel, enc. Nuno Carinhas, ASSéDIO, 2000 (João Cardoso), fot. Henrique Delgado.

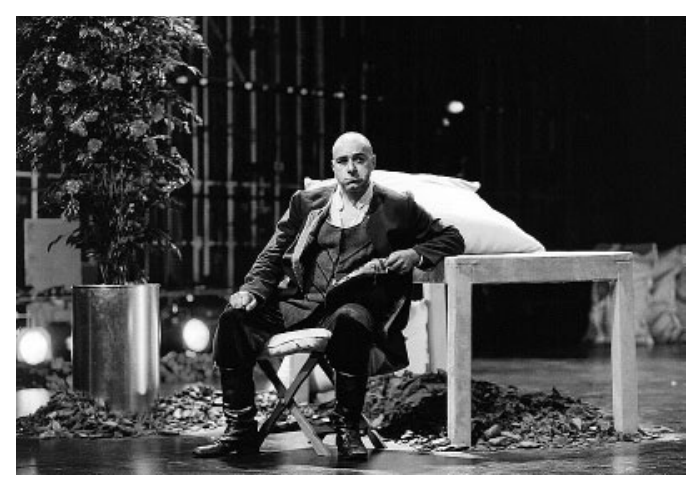

Dama d'água,

de Frank McGuinness, enc. Nuno Carinhas, Ensemble, 2001 (Emilia Silvestre), fot. João Tuna.

discussão pública, o que se prende directamente com preocupações de cidadania. Por um lado estamos a viver um momento de conciliação e de recuperação, tudo aquilo que tem a ver com a "era Obama", mas também há, por outro lado, o sentimento de que tudo isto é muito mais sério do que outros momentos político-económicos nos deram a ver e a experimentar. E isso também é a obrigação de um Teatro Nacional, projectar essas inquietações, por uma questão de cidadania e de ideologia. E acho que esta tentativa, se quiserem, de "politização" do repertório é uma coisa que, neste momento, me interessa. Dai também a tentativa de organizar programas à volta destes projectos susceptiveis de contribuírem para alguma espessura de propósitos. Mas, sim, parece-me existir uma clara inclinação para o incómodo, reconheço, para a reactualização de determinadas questões. Contudo, isso também era algo que já vinha sendo preparado, porque já acontecera, por exemplo, com 0 mercador de Veneza e o ciclo de conferências organizado em torno do texto e do espectáculo. Não sei... o espírito lúdico não é, talvez, uma coisa que me assista de forma muito natural, mas reconheço que ela se pode encontrar na variedade de acontecimentos que se organizam à volta de um objecto, como podem ser os painéis que a Ilda David pintou para o Salão Nobre do TNSJ.

Já há pouco referiste a preocupação com a questão dos públicos e dos espaços. A nossa curiosidade, agora, é a de saber o que é que, com as condicionantes financeiras existentes e conhecidas, neste momento, ainda gostarias de fazer. Quais são os desafios que encaras como mais prementes para o futuro do TNSJ? Se bem que existam mais espaços para que isso aconteça - estou a lembrar-me da ocupação recente do Teatro Latino e do espaço da Fábrica -, eu gostaria de repetir a experiência do 30 por noite [2008], isto é, uma amostragem do que vem sendo feito pelos grupos mais jovens e mais
O triunfo do amor, de Marivaux, enc. João Pedro Vaz, cenografia de Nuno Carinhas, ASSéDIO / TNSJ, 2002 (João Cardoso), fot. João Tuna. 
O tio Vânia

de Anton Tchekov,

enc. e cenografia de

Nuno Carinhas,

TNSJ / ASSÉDIO /

Ensemble, 2005

(Emilia Silvestre

e João Pedro Vaz),

foto. João Tuna.



0 concerto de Giglis

de Tom Murphy,

enc. e cenografia de

Nuno Carinhas,

ASSéDIO / TNSJ, 2008

(João Cardoso

e João Pedro Vaz),

fot. João Tun
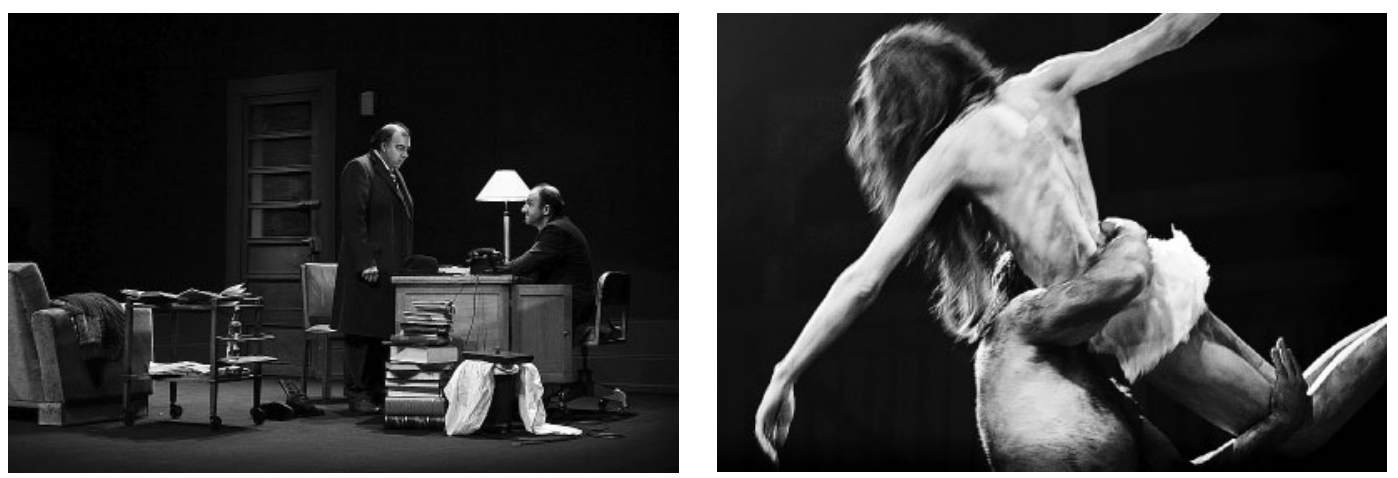

Breve sumário da

história de Deus,

de Gil Vicente,

enc. e cenografia de

Nuno Carinhas,

TNSJ, 2009,

fot. João Tuna.

independentes da cidade. Gostaria também muito de activar as edições e de levar mais longe o trabalho que se vem fazendo. Há, por outro lado, desafios que foram feitos a dramaturgos portugueses para escreverem textos

"cruzados": um deles já está escrito, a adaptação realizada pelo Jacinto Lucas Pires de Judite, nome de guerra, do Almada Negreiros, e há um outro que já está na calha, que é o trabalho que a Luísa Costa Gomes está a fazer sobre Casas pardas, da Maria Velho da Costa. E eu gostava que isto pudesse acontecer muito mais. Seja através desta ideia de adaptação dramatúrgica da ficção portuguesa ou através de outras vias. Uma das coisas que está a faltar é a internacionalização: gostaria que isto funcionasse de forma muito mais ágil, nomeadamente no contexto na União dos Teatros da Europa, mas não é fácil, porque cada país tem as suas idiossincrasias, a sua organização, etc. E provavelmente este não é o momento ideal para nos pormos a movimentar de um lado para o outro, mas seria fulcral. Pela nossa circunstância, pelo nosso estado quase insular, o Teatro não é muito visto lá fora, e eu gostaria de tentar dinamizar mais o circuito de circulação dos nossos espectáculos, com destaque para Espanha e o Brasil, que são os dois paises com maior proximidade geográfica ou cultural. Talvez este ano possamos já ter a

possibilidade de realizar algumas deslocações.

Paralelamente, preocupa-me o facto de não apresentarmos aqui mais espectáculos estrangeiros, porque acho que são sempre momentos em que o próprio tecido profissional se regenera, se renova e expande. Mas qualquer tentativa de, por exemplo, sermos co-produtores de um projecto estrangeiro é completamente utópica, porque não temos recursos para isso... Outra coisa que está a faltar é o teatro para a infância. Enfim, há uma infinidade de projectos que teremos de ir avaliando, pensando e pondo no terreno. 0 desígnio será especular fazendo. Adiar necessidades para melhores dias não é coisa de artistas.

Enquanto não soubermos com antecedência e a médio prazo quais as verbas que nos cabem, dificilmente planeamos em consequência. Mas é essa a aposta. 